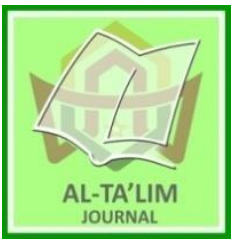

AL-TA'LIM JOURNAL, 28 (2), 2021, (167-179)

(Print ISSN 1410-7546 Online ISSN 2355-7893)

Available online at http://journal.tarbiyahiainib.ac.id/index.php/attalim

\title{
Transformational Leadership: Principal Intellectual Stimulation In Improving Teacher Competences
}

Received: 03 ${ }^{\text {th }}$ July 2021; Revised: 27 ${ }^{\text {th }}$ July 2021; Accepted: 31 ${ }^{\text {th }}$ Juli 2021

Permalink/DOI: $\underline{\text { http://dx.doi.org/10.15548/it.v28i2.708 }}$

Makherus Sholeh

Universitas Islam Negeri Antasari

Banjarmasin, Indonesia.

E-mail: makherus@uin-antasari.ac.id

\begin{abstract}
Various efforts have been made to improve teacher competence, but there are still many institutions that have not optimized teacher capacity development. This study examines the intellectual stimulation of principals in improving teacher competence in two favorite institutions in the East Java region of SDI Qurrota A'yun Tulungagung and MI Perwanida Blitar. This study uses a qualitative descriptive method with a multi-case study design. Data were collected through 16 teachers and one school committee, one student guardian, one community leader, and one employee determined by random purposive sampling. Information was obtained through interviews, documentation, and observation. The results of this study indicate the role of leaders in forming various teacher competency improvement programs; (a) Program in-service education. The leader delegates teachers to improve professional and pedagogical competencies, which consist of advanced study programs, equivalency studies, Teacher Professional Education (PPG), (b) Program in-service training. Leaders delegate teachers to improve pedagogical and professional competencies through training activities, seminars, workshops, and webinars. (c) Leaders conducted program onservice training as a facility to improve teacher competence, (1) Supervision Activities and Teacher Working Groups (KKG), (2) teachers are actively competing, (3) actively writing papers, (4) collaboration activity, (5) social service activities, (6) religious activity (7) Job rotation, (8) Curriculum integration according to the institution's development distinction, (9) Technology-based learning.
\end{abstract}

Keywords: Intellectual stimulation; competency improvement; teacher.

How to Cite: Sholeh, M. (2021). Transformational Leadership: Principal Intellectual Stimulation In Improving Teacher Competences. Al-Ta lim Journal, 28(2), 167-179. doi:https://doi.org/10.15548/jt.v28i2.708

\section{INTRODUCTION}

Improving the quality of education at the micro-level is generally determined by the operationalization of leaders. The role of the leader or principal in carrying out the mobility of his members can provide a spirit of motivation for the teachers to work effectively based on shared interests, giving a positive impact on teachers (Ghorbani \&
Yekta, 2012). Teachers will work seriously and develop their creativity without waiting for the leader's orders and doing the work without involving them. Creating a culture of sincerity in carrying out tasks must start from the top and then the personnel at the bottom (from the top down) (Yulk, 2010), (Dolev \& Leshem, 2017). 
Ensuring that teachers are equipped with these advanced competencies (e.g., knowledge and skills related to professional practice, collaboration and leadership, integrity and commitment to education and social change, etc.) is critical to ensure the success of Education reform (Garet et al., 2001). For this reason, many countries around the world are investing in the continuous learning of their teachers as the main engine for enhancing teacher competence in determining student academic success (Darling-Hammond et al., 2010).

The reality nowadays is that all developing countries, including Indonesia, face low teacher competitiveness (competence) as an indicator that education has not been able to produce teachers who have high quality and integrity who can meet the expectations and needs of the community (Eble et al., 2021). The progress of an educational institution is not determined by the status of a public or private institution, but it is determined by the existing human resources within the educational institution, the principals and teachers.

Several survey results explain that $75 \%$ of UKG results get scores below the average. The data obtained from 10 provinces scored above the average, and the rest were still below the standard. DI Yogyakarta holds the highest score, with an average score of 67.02. Central Java province occupies the second position with an average score of 63.30. DKI Jakarta occupies the third position with an average score of 62.58 with an assigned grade of 7.00 (Kemendikbud 2019). According to research results from the Ministry of Religion of the Republic of Indonesia, teachers who have not been certified amounted to 269.460, consisting of 48,961 civil servants and 220,499 non-civil servants. Meanwhile, the certified teachers amounted to 113, 048 consisting of 40,933 civil servants and 72,115 non-civil servants (RI, 2016). By looking at these data, it has not been proven and maximally the teacher certification program that was initiated to boost a teacher's professionalism. Moreover, many teachers still have the wrong place "mismatch," who holds a subject that is not their expertise (Mufti, 2017).

The teaching profession must be filled with people who love the world of education, are knowledgeable, and have high-quality abilities because they will produce excellent students. However, it is challenging to attract students as learning outputs into the teaching profession (Diaz \& Maggioli, 2004), (Hargreaves \& Fullan, 2012), (Sholeh et al., 2021). In fact, the quality of teachers leads to a static, fragmented, narrow, and instrumented professional image (Snoek, 2021).

As a result, what must be accepted is that the teaching profession is occupied by people who are complacent, do not have the dedication to improve their competence, and are willing to compete. Despite all the complicated problems experienced by teachers in their lives, teachers are still the primary key that determines the success or failure of the learning process in schools (Sholeh et al., 2015). A teacher must also have the passion for always developing and improving the quality of his individual-social. It will be easy to achieve educational goals, developing students with noble character and professional character. The quality of education that is aspired to will be achieved.

One of the factors causing the declining quality of teachers in educational institutions in Indonesia is the lack of professionalism of the principal as an education manager (Mutohar \& Trisnantari, 2014). There has not yet been a spirit of trying to organize education as well as possible, including involving stakeholders. They are clearly seen not taking Islamic educational institutions seriously because their sincerity demands various efforts to always work optimally (Maunah, 2019).

Therefore, the transformational leadership style is expected to be the most appropriate in improving teacher competence. Leaders who have a strong vision and mission, communication, motivation, and management can improve the quality of teachers in the institutions they lead (Inkson 
\& Z, 2011), (Shuck et al., 2018). Besides, it is also necessary for leaders who regularly conduct self-evaluations to see how far the teachers' quality progress is managed. Bernard M. Bass specifically emphasized that a person can be said to have transformational leadership if he has the ability to idealized influence, inspirational motivation, intellectual stimulation, individual consideration (Bass, 1985); (Bass, 1995); (Bass, 1999); (Avolio et al., 1999); (Bass \& Riggio, 2006). The leadership dimension of intellectual stimulation is considered the most appropriate in improving the ability of teachers. Because it has a dominant influence in increasing the ability and knowledge of teachers, (Bolkan et al., 2011)(Al-husseini \& Elbeltagi, 2018).

Behind the chaotic world of education, there is a glimmer of hope from some leaders who can transform their institutions. Among the leaders or principals of schools and madrasahs who can transform their HR competencies to bring their institutions to their distinctive features are SDI Qurrota A'yun Tulungagung and MI Perwanida Blitar. The characteristics of these advantages make both institutions much in demand by local residents. On the other hand, many public and private elementary schools are located around the school environment, but parents prefer private schools whose tuition fees are more expensive.

The teachers at SDI Qurrota A'yun Tulungagung have religious personalities and are fluent in two languages, English and Arabic. The leadership of the SDI Qurota A'yun principal can transform its human resources by increasing professional competence by implementing an international standard curriculum from the Cambridge International Examination (UK) in collaboration with the State University of Malang. The principal brings tutors to guide and train teachers to practice speaking English. Teachers who have never previously taught in English become familiar with using English in the learning process.

Meanwhile, the MI Perwanida Blitar principal presented a leader who excelled by bringing the name of the madrasah and the City of Blitar by winning 2nd position for the best MI Headmaster according to achievements at the East Java Province level. In addition, the principal can transform teacher competence so that it has an impact on educators and students achieving various national and international achievements. The institution's achievements won the city level Adiwiyata Madrasah, East Java Province Adiwiyata, National Adiwiyata, and Mandiri Adiwiyata.

Understanding the uniqueness of both institutions, this study aimed to examine the intellectual stimulation behavior of principals in improving teacher competence in two Islamic primary education institutions, SDI Qurrota A'yun Tulungagung and MI Perwanida Blitar. This research aims to explore the policies or programs of principals in solving various problems faced to improve teacher competence. The results of this study are expected to provide an overview of the dimensions of intellectual stimulation in improving teacher competence and become input and consideration for school principals and policymakers to improve teacher competence.

\section{METHOD}

This type of research is descriptive qualitative field research. The approach that is considered suitable in this research is naturalistic phenomenology (Creswell, 2009). Research from a phenomenological perspective is to understand the meaning of events and principal interactions in providing intellectual stimulation to teachers to improve their competence. This study uses a multicase study design.

Determining the source of information, researchers conduct direct observations to reveal and explore facts that strengthen the theory consisting of person, place, and paper. Data were collected through observation, interviews, and documentation. Determination of this key informant (person) is the principal and supporting informants consisting of 16 teachers, one school committee, one student guardian, one community leader, and one 
employee. The research location (place) is at SDI Qurrota A'yun Tulungagung and MI Perwanida Blitar. Data paper were in the form of symbols or artifacts in the form of written objects such as work manuals, madrasah profiles, photos, records, and various documents published on websites, YouTube, Facebook, and Instagram are related to transformational leadership in improving the competence of SDI Qurrota A'yun Tulungagung teachers and MI Perwanida Blitar.

Then, the data collected was analyzed using data reduction techniques for each case at the research location, presenting data, and drawing conclusions. Checking the validity of the data by taking into account a) the degree of confidence such as discussion and triangulation: sources, techniques, time, and theory; b) transferability; c) dependability; and d) confirmability.

\section{RESULT AND DISCUSSION}

This type of research is descriptive qualitative field research. The approach that is considered suitable in this research is naturalistic phenomenology (Creswell, 2009). Research from a phenomenological perspective is to understand the meaning of events and principal interactions in providing intellectual stimulation to teachers to improve their competence. This study uses a multicase study design.

Determining the source of information, researchers conduct direct observations to reveal and explore facts that strengthen the theory consisting of person, place, and paper. Data were collected through observation, interviews, and documentation. Determination of this key informant (person) is the principal and supporting informants consisting of 16 teachers, one school committee, one student guardian, one community leader, and one employee. The research location (place) is at SDI Qurrota A'yun Tulungagung and MI Perwanida Blitar. Data paper were in the form of symbols or artifacts in the form of written objects such as work manuals, madrasah profiles, photos, records, and various documents published on websites,
YouTube, Facebook, and Instagram are related to transformational leadership in improving the competence of SDI Qurrota A'yun Tulungagung teachers and MI Perwanida Blitar.

Then, the data collected was analyzed using data reduction techniques for each case at the research location, presenting data, and drawing conclusions. Checking the validity of the data by taking into account a) the degree of confidence such as discussion and triangulation: sources, techniques, time, and theory; b) transferability; c) dependability; and d) confirmability.

Table 1. Intellectual Stimulation Leaders In Improving Teacher Competence

\begin{tabular}{|c|c|c|}
\hline Dimensions & Activities & Competence \\
\hline $\begin{array}{l}\text { Program In- } \\
\text { service Education }\end{array}$ & $\begin{array}{l}\text { Advanced study } \\
\text { Qualification } \\
\text { Equalization } \\
\text { Study } \\
\text { Teacher } \\
\text { Professional } \\
\text { Education }\end{array}$ & $\begin{array}{c}\text { Professional } \\
\text { and } \\
\text { Pedagogic } \\
\text { Competence }\end{array}$ \\
\hline $\begin{array}{c}\text { Program In- } \\
\text { service Training }\end{array}$ & $\begin{array}{l}\text { Seminar } \\
\text { Webinar } \\
\text { Training } \\
\text { Workhsop }\end{array}$ & $\begin{array}{c}\text { Professional } \\
\text { and } \\
\text { Pedagogic } \\
\text { Competence }\end{array}$ \\
\hline $\begin{array}{l}\text { Program On- } \\
\text { service Training }\end{array}$ & $\begin{array}{l}\text { Supervision } \\
\text { Teacher Working } \\
\text { Group (KKG) } \\
\text { Actively Compete } \\
\text { Writing Papers } \\
\text { Featured } \\
\text { Collaboration } \\
\text { Programs } \\
\text { Social activities } \\
\text { Religious activity } \\
\text { Job Rotation } \\
\text { Curriculum } \\
\text { Integration } \\
\text { Technology } \\
\text { Based Learning }\end{array}$ & $\begin{array}{c}\text { Professional } \\
\text { Competence, } \\
\text { Pedagogy, } \\
\text { Social, } \\
\text { Personality, } \\
\text { Spiritual, } \\
\text { and } \\
\text { Leadership }\end{array}$ \\
\hline
\end{tabular}

\section{In-service Education Program in Improving Teacher Professionalism}

\section{Improved educational qualifications.}

Intellectual Stimulation provided by leaders in both institutions to improve teacher professionalism by providing opportunities and supporting teachers to improve further education qualifications at the master and doctoral degree. Continuing further studies 
will deepen the understanding of educational insight, understand more deeply about the concepts, structures, and scientific methods that are mastered, and deepen the mastery of the material (KONAPSI, 2016). According to research results by (Guo et al., 2007) and (Williams, 2011), they explained that teachers with higher qualifications showed more support and positively impacted the classroom environment than teachers with lower qualifications. The pedagogical competence and professionalism of teachers can be obtained, indicated by the consistency of teachers for further study and learning (Huber, 2010; J.Caldwell, 2001)(Huber, 2010). By increasing teacher qualifications, make substantial progress in reducing the structural inequalities of the education system (Long \& Wendt, 2019).

Equal Studies and Following Teacher Professional Education (PPG).

In both institutions, intellectual stimulation provided by leaders in improving pedagogic and professional competencies was also carried out by providing support to teachers for equalization studies and participating in PPG. Equalization studies strengthen scientific concepts, strengthen teaching strategies, curriculum and technology understanding. With equalization studies, the realization of teacher professionalism, students can learn and gain more experience (J.Caldwell, 2001).

The purpose of participating in teacher professional education (PPG) is to obtain teacher certification. The most striking thing with the certification is the growing enthusiasm of teachers in both institutions to participate in various scientific activities in various institutions or universities. Contrary to the results of research by (Kusumawardhani, 2017) who explains that there is not strong enough evidence of the effectiveness of certified teachers on student learning outcomes and teacher performance or professionalism.

Transformational leadership in improving professional competence and pedagogy through in-service education programs such as increasing qualifications, equalization studies, and participating in teacher professional education (PPG) has a positive effect on increasing teacher knowledge and skills, including mastery of curriculum concepts, assessment approaches, mastery of technology, and mastery of teaching strategies with a diverse student population. In addition, there has been a change in teaching practice as a result of more creative and innovative professional development and pedagogical activities.

\section{In-service Training Program in Improving Teacher Professionalism}

Intellectual stimulation of leaders in both institutions in improving pedagogic and professional competencies is by delegating teachers to participate in activities in the form of training, seminars, workshops, and webinars externally and internally by the institution. If teachers participating in various activities, students can learn more and varied (Lockhart, 2000)). Following the opinion by Diaz and Maggioli to improve teacher competence, it is a need delegating or financing teachers who have the potential to participate in various activities outside schools, such as attending conferences and seminars, training, and workshop (Diaz \& Maggioli, 2004).

Training programs attended by teachers have an effect on teacher competence and assignment programs at the class and institutional level (Veenman et al., 1994). Demonstrate increased ability and interest in reflecting with colleagues regarding the problems encountered in learning (Cherubini et al., 2002). Increased conceptual knowledge predicts instructional planning, controlling experiences, and beliefs. Addressing the gaps linking belief and knowledge with planning in teaching (Lui \& Bonner, 2016).

Andrzej Cirocki and Thomas SC Farrell looking at it from a different point of view, research in Indonesia shows that although teachers say they have many opportunities to develop professionally, not everyone takes advantage of them (Cirocki \& Farrell, 2019). Therefore, the role of the 
leader/principal is needed to motivate and continue to send/delegate teachers to participate in various forms of training activities, seminars, workshops, and webinars in order to strengthen scientific mastery in accordance with their fields, as a form of reflection, self-development and can be implemented in learning.

\section{On-service Training Program in Improving Teacher Professionalism}

Leaders provide intellectual stimulation in improving teacher competence with the Inservice Training Program, which consists of supervision activities, actively participating in teacher working groups (KKG), writing scientific papers and publishing them, actively competing teachers, excellent collaboration programs, social service programs, religious activities, rotation positions, curriculum integration, and technology-based learning.

Supervise and actively participate in teacher working groups (KKG). Intellectual stimulation leaders in both institutions in improving teacher professionalism, actively supervising or mentoring (Hidayat \& Wulandari, 2020). External and internal KKG in order to strengthen the professional competence and pedagogy of teachers in solving various problems in learning such as determining the most appropriate model, strategy, approach and can improve student learning outcomes. (Aziz et al., 2020); (Rahmi et al., 2020).

\section{Actively Compete}

Intellectual stimulation leader in both institutions in improving professional competence and pedagogy is by providing instructional training to participate in various teacher competitions. From the two institutions, many teachers excel at regional and national levels. The principal's policy in sending teachers to participate in various competitions can generate teacher motivation to excel. By interactively participating in an outstanding teacher competition, it will provide experience, hone the scientific ability of teachers in the development of science and foster an attitude of self-efficacy for teachers to excel ((Ford et al., 2017), (Liu, 2020). Of course, with teachers actively competing, it motivates students to participate in achievements (Nurabadi et al., 2021).

\section{Actively write scientific papers}

Intellectual stimulation of leaders in both institutions in improving teacher professionalism is by generating teacher efficacy to write essays. Writing scientific papers at SDI Qurrota A'yun by providing a forum in the form of the GReSS magazine, which is published every semester. The magazine is filled with written works of students and educators. Meanwhile, writing scientific papers at MI Perwanida by creating posters from teachers and students. In addition, the madrasah principal supports educators and students in publishing their written works. So, many written works are created by educators and students published in print media such as newspapers, books, modules, and writing class action research (CAR).

In the future, in developing professional programs, teachers must master the use of technology as a tool to support writing papers or mastering digital literacy (Mina, 2019), (Arifin et al., 2021). Steps that can be taken by leaders are developing strategies for increasing professionalism by encouraging writing, which must be supported by an individual teacher and group literacy (Vansteelandt et al., 2020). Professional development for writing teachers should provide instructional strategies that enable teachers to act in writing (Beck et al., 2018).

\section{Collaboration Program}

Intellectual Stimulation of school principals in improving professional, pedagogical, social, personality, spiritual, and leadership competencies of principals in both institutions creates collaborative programs with the community. With this collaboration program, especially those related to the world of education, it is possible to improve the ability to communicate and socialize on a 
micro and macro scale (Ulfatin \& Triwiyanto, 2018). The school collaborates with campus academics in East Java, parents and guardians of students, doctors, police, TNI, lecturers, and other institutions. In the application, the guardians of students teach with various themes according to the field of guardians of students' jobs and cooperate with environmental institutions. Leader collaboration programs will have a positive impact on student learning by building school capacity for academic improvement (Hallinger \& Heck, 2010). Education programs in schools cannot be achieved if they are not supported by families and communities (Maunah, 2019).

\section{Social Service Activities}

Intellectual stimulation of leaders in both institutions in improveing personality, social, spiritual, and leadership competencies is by making social service programs. As for the social service activities carried out every Friday, there is charity Friday activities. Proceeds from Friday charity activities can be used, such as scholarships for underprivileged parents and for areas affected by disasters, such as donations of clean water in areas with difficulty getting clean water in the dry season and various other social activities. Participating in social service activities can foster an attitude of empathy and sympathy for individual teachers towards the surrounding environment. Educators who always improve spiritual competence by reviving good character in their hearts will more easily realize the ideals of education (Sholeh, 2016), (Sholeh, 2018) (Zulfatmi, 2017).

\section{Religious Activity}

Intellectual stimulation of leaders in both institutions in improving spiritual, personality, social, and leadership competencies is by holding religious activities. Just as leaders habituate praying dhuha, dhuhur in a congregation, reciting yasin and tahlil, praying before and after learning, getting used to $3 \mathrm{~S}$ (smiles, greetings), studying Kitab Kuning, Pondok Ramadhan, commemorating the Prophet's birthday, etc. With religious activities, leaders can share life theories to help others develop, inculcate practice in daily life, strengthen the spiritual and character of teachers (Diaz \& Maggioli, 2004) (Nishimura, 2014). Through religious activities in schools as an essential dimension/component of education that has an important impact on the moral health of the nation and as a factor that affects human welfare (Niculescu \& Norel, 2013).

\section{Position Rotation}

Intellectual stimulation leaders in both institutions also instill or develop leadership competencies for their subordinates by rotating positions. Position rotation is carried out in positions that are in structural and nonstructural activities. As well as rotating homeroom teachers and assistants for extracurricular activities, being in charge of other activities such as Religious Holidays, National Holidays, and Annual Events. Job rotation shows that teachers have the potential to build social capital in organizations by training teachers in developing teacher leadership capacity (Shea et al., 2020). According to Ling $\mathrm{Li}$ and Yan Liu, teacher leadership has an impact on improving student learning and improving the quality of schools with various academic achievements obtained by students (Li \& Liu, 2020). In accordance with the facts in the field, there are many academic achievements obtained by students at the district/city regional, national, and international levels. In accordance with the research results by Ryan H Shatzer et al., the leadership style of principals who rotate positions tends to have a significant impact on student achievement (Shatzer et al., 2014).

\section{Curriculum Integration}

Intellectual Stimulation leaders in both institutions to develop teachers' pedagogic and professional competencies is by integrating the curriculum. There is something different about the two leaders of SDI Qurrota A'yun integrating the national curriculum with the Cambridge curriculum. Meanwhile, MI Perwanida Blitar integrates the national curriculum with Adiwiyata. The leader gives freedom to the teacher to develop 
in compiling lesson plans and worksheets in following the institution's development characteristics. The curriculum integration policy carried out by the principal to obtain and utilize the followers' actual knowledge and develop the potential of their followers (Robinson, 2018). The integration of the curriculum developed by school principals and teachers will affect student achievement. In addition to having an impact on teachers, curriculum development will develop highquality school leaders, ((Quin et al., 2015).

\section{Technology-Based Learning}

Both institutions provide freedom in developing learning media by providing facilities in the form of an internet network and LED TV that teachers can use in the learning process. The two principals also create a youtube channel as a learning media where teachers can create creative learning videos according to their field needs while evaluating using CBT. Here the teacher is involved in the process of developing/improving (involvement in a development/improvement process) technology-based learning ((Nata, 2019); (Calavia et al., 2021)). In accordance with the research results by Printy et al. and Benjamin Faut et al., the competence of teachers supported by conducive relationships can improve the quality of learning and create conditions that support the academic progress of all students. (Printy et al., 2009), (Fauth et al., 2019). Principals as policymakers have budget allocations for educational technology tools that will help teachers and students improve the teaching and learning process (Santos \& Castro, 2021).

From the description above, the intellectual stimulation of leaders in improving teacher competence has a very dominant influence with various activities conducted internally and externally. With various activities conducted, institutional leaders have a role in improving teachers' professional, pedagogic, social, personality, spiritual, and leadership competencies following the distinctions given by the institution. In line with the research results of Sawasn Al-Husseini \& Ibrahim Elbeltagi, from the four components of transformational leadership, intellectual stimulation has the strongest effect (Al-husseini \& Elbeltagi, 2018), also reinforced with (Nurabadi et al., 2021) The results of his research explain that instructional and transformational leadership styles affect teacher performance and impact student achievement. The on-service training program can improve professional, pedagogical, social, personality, spiritual, and leadership competencies. Teachers solve various problems encountered in learning: 1) enhance knowledge and abilities following their talents and interests, 2) improve communication and social skills on a micro and macro scale, 3) increase values, attitudes of sympathy and empathy, spiritual and leadership qualities, and 4) improve teacher abilities in mastering information technology in facing the challenges of the times.

\section{CONCLUSION AND RECOMMENDATION}

The Intellectual Stimulation dimension places leaders in improving teacher competence by stimulating educators to be more innovative and creative, reviewing things, and bringing old situations into new styles. Creativity is a priority and is shown by making various improvement programs as a forum for teacher creativity in improving the knowledge, understanding, abilities, values, and interests of teachers according to their expertise.

In practice, leaders improve their professional, pedagogical, social, personality, spiritual, and leadership competencies by helding various program activities. The activities are In-service Education Programs, In-service Training Programs, and On-service Training Programs as a continuation or Follow-up activity conducted by holding regular discussions among teachers and always maintaining communication with professional partners, family spirit, and social solidarity.

\section{REFERENCES}

Al-husseini, S., \& Elbeltagi, I. (2018). Evaluating the effect of 
transformational leadership on knowledge sharing using structural equation modelling: The case of Iraqi higher education. International Journal of Leadership in Education, 21(4), 506-517. https://doi.org/10.1080/13603124.201 6.1142119

Arifin, M., Sholeh, M., Hafiz, A., Agustin, R., \& Wardana, M. (2021). Developing Interactive Mobile Mathematics Inquiry to Enhance Students' Mathematics Problem-solving Skil. International Journal of Interactive Mobile Technologies, 15(1), 24-38. https://doi.org/10.3991/IJIM.V15I01.2 0067

Avolio, Bass, B. M., \& Jung. (1999). ReExamining the Components of Transformational and Transactional Leadership Using the Multifactor Leadership Questionnaire. Journal of Occupational and Organizational Psychology, 72(441), 462.

Aziz, Abd., Sari, N. R., Sibilana, A. R., Muniri, \& Surahmat. (2020). Improving Student Achievement Using Flipchart Based Cooperative Learning in Tulungagung. Universal Journal of Educational Research, 8(10), 4628-4633. https://doi.org/10.13189/ujer.2020.081 031 .

Bass, B. M. (1985). Leadership and Performance Beyond Expectations. The Free Press.

---. (1995). Theory of Transformational Leadership Redux. The Leadership Quarterly, 6(4), 453-471. https://doi.org/10.1177/ 002246699202500404

---. (1999). Two Decades of Research and Development in Transformational Leadership. European Journal of Work and Organizational Psychology, 8(1), 9-32. https://doi.org/10.1080/135943299398 410
Bass, B. M., \& Riggio, R. E. (2006). Transformational Leadership (second). Lawrence Erlbaum Associates Publishers.

Beck, S. W., Llosa, L., Black, K., \& Anderson, A. T. G. (2018). From assessing to teaching writing: What teachers prioritize. Assessing Writing, 37(March), https://doi.org/10.1016/j.asw.2018.03. 003

Bolkan, S., Goodboy, A. K., \& Griffin, D. J. (2011). Teacher leadership and intellectual stimulation: Improving students' approaches to studying through intrinsic motivation. Communication Research Reports, 28(4), 337-346. https://doi.org/10.1080/08824096.201 1.615958

Calavia, M. B., Blanco, T., \& Casas, R. (2021). Fostering creativity as a problem-solving competence through design: Think-Create-Learn, a tool for teachers. Thinking Skills and Creativity, 39(November 2020). https://doi.org/10.1016/j.tsc.2020.100 761

Cherubini, G., Zambelli, F., \& Boscolo, P. (2002). Student motivation: An experience of inservice education as a context for professional development of teachers. Teaching and Teacher Education, 18(3), 273-288. https://doi.org/10.1016/S0742051X(01)00069-5

Cirocki, A., \& Farrell, T. S. C. (2019). Professional development of secondary school EFL teachers: Voices from Indonesia. System, 85, 102111.

https://doi.org/10.1016/j.system.2019. 102111

Creswell, J. W. (2009). Research Design: Qualitative, Quantitative and Mixe Methods Approaches. (Third). SAGE Publication. 
Darling-Hammond, L., Chung Wei, R., \& Andree, A. (2010). How HighAchieving Countries Develop Great Teachers. Stanford Centre for Opportunity Policy in EducationResearch Brief, 1-8.

Diaz, G., \& Maggioli. (2004). Teacher Centered Professional Development. In Healthcare Executive (Vol. 21, Issue 3). Association for Supervision and Curriculum Development (ASCD).

Dolev, N., \& Leshem, S. (2017). Developing emotional intelligence competence among teachers. Teacher Development, 21(1), 21-39. https://doi.org/10.1080/13664530.201 6.1207093

Eble, A., Frost, C., Camara, A., Bouy, B., Bah, M., Sivaraman, M., Hsieh, P. T. J., Jayanty, C., Brady, T., Gawron, P., Vansteelandt, S., Boone, P., \& Elbourne, D. (2021). How much can we remedy very low learning levels in rural parts of low-income countries? Impact and generalizability of a multipronged para-teacher intervention from a cluster-randomized trial in the Gambia. Journal of Development Economics, 148, 102539. https://doi.org/10.1016/j.jdeveco.2020 .102539

Fauth, B., Decristan, J., Decker, A. T., Büttner, G., Hardy, I., Klieme, E., \& Kunter, M. (2019). The effects of teacher competence on student outcomes in elementary science education: The mediating role of teaching quality. Teaching and Teacher Education, 86, 102882. https://doi.org/10.1016/j.tate.2019.102 882

Ford, T. G., Van Sickle, M. E., Clark, L. V., Fazio-Brunson, M., \& Schween, D. C. (2017). Teacher Self-Efficacy, Professional Commitment, and HighStakes Teacher Evaluation Policy in Louisiana. Educational Policy, 31(2),
202-248.

https://doi.org/10.1177/089590481558 6855

Garet, M. S., Porter, A. C., Desimone, L., \& Birman, B. F. (2001). What Makes Professional Development Effective? Results From a National Sampleof Teachers. American Educational Research Journal, 38(4), 915-945. https://doi.org/10.3102/000283120380 04915

Ghorbani, M., \& Yekta, S. (2012). A Study of Relationship Between Transformational Leadership and Personnel Creativity in Higher Education Centers. World Applied Sciences Journal, 17(6).

Guo, Y., Connor, C. M., Yang, Y., Roehrig, A. D., \& Frederick, J. (2007). The effects of teacher qualification, teacher self-efficacy, and classroom practices on fifth graders' literacy outcomes. The Elementary School Journal, 107(5), 499-503. https://doi.org/10.1086/518627

Hallinger, P., \& Heck, R. H. (2010). Collaborative leadership and school improvement: Understanding the impact on school capacity and student learning. School Leadership and Management, 30(2), 95-110. https://doi.org/10.1080/136324310036 63214

Hargreaves, A., \& Fullan, M. (2012). Professional Capital: Transforming Teaching In Every School. Teachers College Press.

Hidayat, N., \& Wulandari, F. (2020). The impact of leadership behavior on school performance. Cakrawala Pendidikan, 39(3), 493-506. https://doi.org/10.21831/cp.v39i3.310 05

Huber, M. T. (2010). Caring for students: Pedagogy and professionalism in an age of anxiety. Emotion, Space and Society, $3(2), \quad 71-79$. 
https://doi.org/10.1016/j.emospa.2009. 06.002

Inkson, K., \& Z, K. (2011). Contested Terrain in Careers: A Psychological Contract Model. Human Relations, 64(1), 3757.

https://doi.org/:10.1177/00187267103 84289.

J.Caldwell, B. (2001). Leadership in the Creation of World Class Schools: Beyond the Self-Managing School. In Leadership for Quality Schooling International Perspectives (Vol. 1, pp. 145-163). Routledge.

KONAPSI. (2016). Konvensi Nasional Pendidikan Indonesia (KONAPSI) VIII.

Kusumawardhani, P. N. (2017). Does teacher certification program lead to better quality teachers? Evidence from Indonesia. Education Economics, 25(6), 590-618. https://doi.org/10.1080/09645292.201 7.1329405

Li, L., \& Liu, Y. (2020). An integrated model of principal transformational leadership and teacher leadership that is related to teacher self-efficacy and student academic performance. Asia Pacific Journal of Education, 00(00), $1-18$.

https://doi.org/10.1080/02188791.202 0.1806036

Liu, I. F. (2020). The impact of extrinsic motivation, intrinsic motivation, and social self-efficacy on English competition participation intentions of pre-college learners: Differences between high school and vocational students in Taiwan. Learning and Motivation, 72(February), 101675. https://doi.org/10.1016/j.lmot.2020.10 1675

Lockhart, J. C. R. and C. (2000). Reflective Teaching in Second Language Classrooms, (London). Cambridge University Press.
Long, C., \& Wendt, H. (2019). Trends in Qualification of South African Mathematics Teachers: Findings from TIMSS 2003, 2011, 2015. African Journal of Research in Mathematics, Science and Technology Education, 23(3), 344-353. https://doi.org/10.1080/18117295.201 9.1692475

Lui, A. M., \& Bonner, S. M. (2016). Preservice and inservice teachers' knowledge, beliefs, and instructional planning in primary school mathematics. Teaching and Teacher Education, 56, 1-13. https://doi.org/10.1016/j.tate.2016.01. 015

Maunah, B. (2019). The Contribution of Family and Community Education in Realizing the Goals of School Education. American Journal of Education and Learning, 4(2), 292301. https://doi.org/10.20448/804.4.2.292.3 01

Mina, L. W. (2019). Analyzing and Theorizing Writing Teachers' Approaches to Using New Media Technologies. Computers and Composition, 52, 1-16. https://doi.org/10.1016/j.compcom.20 19.01.002

Mufti, A. Y. A.-. (2017). Kompetensi Profesional Guru Mismatch PAI Di Madrasah Ibtidaiyah Pecangaan Jepara. Elementary, 5(1).

Mutohar, P. M., \& Trisnantari, H. E. (2014). The Effectiveness of Madrasah: Analysis of Managerial Skills, Learning Supervision, School Culture, and Teachers' Performance. Malaysian Online Journal of Education, 2(1), 48-61.

Nata, A. (2019). Pengembangan Profesi Keguruan dalam Prespektif Islam. Raja Grafindo Persada. 
Niculescu, R. M., \& Norel, M. (2013). Religious Education an Important Dimension of Human's Education. Procedia - Social and Behavioral Sciences, $\quad 93, \quad 338-342$. https://doi.org/10.1016/j.sbspro.2013. 09.200

Nishimura, T. (2014). Effective Professional Development of Teachers: A Guide to Actualizing Inclusive Schooling. International Journal of Whole Schooling, 10(1).

Nurabadi, A., Irianto, J., Bafadal, I., Juharyanto, Gunawan, I., \& Adha, M. A. (2021). The effect of instructional, transformational and spiritual leadership on elementary school teachers' performance and students' achievements. Cakrawala Pendidikan, 40(1), $17-31$. https://doi.org/10.21831/cp.v40i1.356 41

Printy, S. M., Marks, H. M., \& Bowers, A. J. (2009). Integrated Leadership: How Principals and Teachers Share Transformational and Instructional Influence. Journal of School Leadership, 19(5), 504-532. https://doi.org/10.1177/105268460901 900501

Quin, J., Deris, A., Bischoff, G., \& Johnson, J. (2015). Comparison of Transformational Leadership Practices: Implications for School Districts and Principal Preparation. Journal of Leadership Education, 14(3), 71-86. https://doi.org/10.12806/v14/i3/r5

Rahmi, E., Patoni, A., \& Sulistyorini, S. (2020). The Management of Human Resources Development in Increasing the Quality of Islamic Education Institutions. Al-Ta Lim Journal, 27(2), 166-178.

https://doi.org/10.15548/jt.v27i2.624

RI, K. A. (2016). Statistik Pendidikan Tahun 2015/2016. Dirjenpendis Bagian Perencanaan dan Sistem Informasi.
Robinson, V. M. J. (2018). Embedding Leadership in Task Performance. In Leadership for Quality Schooling International Perspectives (Vol. 1, pp. 90-102). Routledge.

Santos, J. M., \& Castro, R. D. R. (2021). Technological Pedagogical content knowledge (TPACK) in action: Application of learning in the classroom by pre-service teachers (PST). Social Sciences \& Humanities Open, 3(1), 100-110. https://doi.org/10.1016/j.ssaho.2021.1 00110

Shatzer, R. H., Caldarella, P., Hallam, P. R., \& Brown, B. L. (2014). Comparing the effects of instructional and transformational leadership on student achievement: Implications for practice. Educational Management Administration and Leadership, 42(4), 445-459.

https://doi.org/10.1177/174114321350 2192

Shea, D., Alemu, D. S., \& Visser, M. J. (2020). A social network study of transformational teacher influence. Teacher Development, 00(00), 1-23. https://doi.org/10.1080/13664530.202 0.1818614

Sholeh, M. (2016). Pendidikan Karakter Melalui Implementasi Budaya Religius di Sekolah (Studi di SD LPI Zumrotus Salamah Tulungagung). AlAdzka: Jurnal Ilmiah Pendidikan Guru Madrasah Ibtidaiyah, 6(1), 129150.

https://doi.org/10.18592/aladzkapgmi. v6i1.1648

---. (2018). Implementation of Prophetic in Primary Education Institutions. EDUKASI: Jurnal Pendidikan Islam, 6(2), 54-73. https://doi.org/10.5281/edukasi.v6i2.3 39

Sholeh, M., Jannah, R., Mahmudah, M., \& Khairunnisa, $\mathrm{K}$. (2015). Pengembangan Model Pembelajaran 
Efektif dan Bermakna di MI Perwanida Blitar. Muallimuna : Jurnal Madrasah Ibtidaiyah, 3(2), 116-127. http://dx.doi.org/10.31602/muallimun a.v6i2.4301

Sholeh, M., Patoni, A., \& Aziz, A. (2021). Transformational Leadership: Principal's Idealized Influence in Improving Teacher Competence. International Journal of Science Arts and Commerce, 6(5), 209-219.

Shuck, B., McDonald, K., Rocco, T. S., Byrd, M., \& Dawes, E. (2018). Human Resources Development and Career Development: Where are $\mathrm{We}$, and Where Do We Need to Go. New Horizons in Adult Education and Human Resource Development, 30(1), 3-18.

https://doi.org/10.1002/nha3.2018.30.i ssue-1

Snoek, M. (2021). Educating quality teachers: How teacher quality is understood in the Netherlands and its implications for teacher education. European Journal of Teacher Education. https://doi.org/10.1080/02619768.202 1.1931111

Ulfatin, N., \& Triwiyanto, T. (2018). Manajemen Sumber Daya Manusia Bidang Pendidikan. Raja Grafindo Persada.
Vansteelandt, I., Mol, S. E., Vanderlinde, R., Lerkkanen, M. K., \& Van Keer, H. (2020). In pursuit of beginning teachers' competence in promoting reading motivation: A mixed-methods study into the impact of a continuing professional development program. Teaching and Teacher Education, 96, 103154.

https://doi.org/10.1016/j.tate.2020.103 154

Veenman, S., Tulder, M. Van, \& Voeten, M. (1994). The Impact of Inservice training on Teacher Behaviour. Teacher and Teacher Education, 20(3), 303-317. https://doi.org/10.1016/0742051X(93)E0001-8

Williams, R. (2011). The contribution of gaining an academic qualification to teachers' professional learning. Journal of Education for Teaching, $37(1)$, 37-49. https://doi.org/10.1080/02607476.201 1.538270

Yulk, G. (2010). Leadership in Organization. Pearson.

Zulfatmi, Z. (2017). Kompetensi Spiritual Pendidik (Suatu Kajian pada Unsur Kalbu). Jurnal MUDARRISUNA: Media Kajian Pendidikan Agama Islam, $\quad 7(2), \quad 149$. https://doi.org/10.22373/jm.v7i2.2360 